\title{
FROM THE FIRM TO THE NETWORK: GLOBAL VALUE CHAINS AND EMPLOYMENT RELATIONS THEORY
}

\author{
Tashlin Lakhani \\ Cornell University \\ ILR School \\ 374 Ives Hall \\ Ithaca, NY, 14853 \\ Tel: 607-379-9814 \\ Email: t1336@cornell.edu \\ Sarosh Kuruvilla \\ Cornell University \\ Email: sck4@cornell.edu \\ Ariel Avgar \\ University of Illinois at Urbana Champaign \\ Email: avgar@illinois.edu
}

British Journal of Industrial Relations, Volume 51, No. 3 (September 2013)

Acknowledgements: The authors would like to thank participants at the BJIR $50^{\text {th }}$ Anniversary Conference, participants at the $5^{\text {th }}$ Annual People and Organizations Conference, and Paul Marginson, Rebecca Givan, Eddy Donnelly and Jack Fiorito for invaluable feedback on earlier versions of the article. 


\begin{abstract}
We posit that traditional employment relations theories that focus on individual firms embedded in distinct national institutional contexts are no longer adequate for the analysis of employment relations in a globalized era where production and services are increasingly coordinated across countries and firms. Building on Global Value Chain theory, we introduce a configurational framework that explicitly addresses the employment relations implications of the interconnections within and between firms in the global economy. We argue that different value chain configurations will evidence different employment relations patterns and we validate our framework by applying it to the study of three contemporary global issues. In sum, the framework permits a shift in the focus of employment relations scholarship away from the individual firm to the global networks in which they belong, and hence provides a new theoretical lens for the analysis of employment relations in the global economy.
\end{abstract}




\section{Introduction}

The profound effects of globalization on the strategies and structures of organizations have called into question the adequacy of existing theoretical frameworks for understanding and analyzing employment relations. The dominant employment relations theories in use today focus on the firm embedded in distinct national institutional contexts (e.g. Kochan Katz and McKersie 1986) or on the analysis and implications of different national contexts for firms (e.g. Varieties of Capitalism). Globalization however, characterized by production and services that are increasingly coordinated across countries and firms, requires an analysis of the different linkages between a variety of firms across a variety of national contexts. Thus, there is a need for new theoretical lenses that are sufficiently nuanced to capture the diverse employment systems that are likely to arise from these varied linkages and interdependencies inherent to a global context.

In this paper, we propose that the Global Value Chain (GVC) theory, developed in sociology and based on transaction cost economics, network, and organizational learning theories, can provide scholars with a new framework for understanding employment relations across interlinked firms and countries. We argue that the focus of employment relations analysis should shift away from the individual firm to the interconnected networks in which they belong. GVC theory suggests that different value chains create different relationships between firms in the network operating under multiple national systems. As such, we propose that employment relations will also vary across value chains. There is emerging research that has begun to incorporate GVC perspectives into the analysis of different employment relations phenomena (e.g. Bair and Ramsay 2003; Knorringa and Pegler 2006; Riisgaard and Hammer 2011; Robinson and Rainbird 2011). We draw on and move beyond these studies to develop a framework based on GVC theory that systematically highlights how key employment system criteria vary across 
value chain configurations. In doing so, this framework contributes to the study and practice of employment relations.

\section{Traditional Employment Relations Frameworks}

In this section, we review two frameworks that examine how firm level employment relations are shaped by key actors and the external environment (Dunlop's Industrial Relations System and Kochan, Katz and McKersie's Strategic Choice Framework) ${ }^{1}$ and two that focus on how national institutional configurations affect firm level employment relations strategies (Whitley's National Business Systems approach and the Varieties of Capitalism perspective by Hall and Soskice).

In his book Industrial Relations Systems, Dunlop (1958) argued that the major output of the industrial relations system is a "body of rules created to govern the actors at the work place and work community" (p. 7). These rules are a product of interactions between three key actors, management, labor and the government, who are tied together by a common ideology, and are responding to changes in three environmental contexts, namely markets, technology and societal power relations. Dunlop's theory recognized the centrality of the firm's external environment and its effect on the employment relationship. This systemic view of the employment relationship contributed to the understanding of the interdependencies between actors. Dunlop's framework, however, has been criticized for, among other things, being too static, failing to specify how change occurs in industrial relations, and not capturing interactions and strategic choices made by actors.

Kochan, Katz and McKersie (1986) proposed an alternative framework that not only emphasized the role of the external environment but also stressed the strategic choices made by 
management, and, to a lesser extent, labor and the government, as being critical for understanding employment relations processes and outcomes. They also stressed multiple levels of interaction amongst the actors that went beyond Dunlop's focus on the functional level of collective bargaining and personnel policy making. They highlighted the role of the strategic level (where decisions over business strategies and investments are made) and the workplace level (where policies are administered and where supervisors, employees and union representatives interact on a daily basis).

Kochan, Katz and McKersie's framework is, however, a firm-centered approach, anchored in a view of organizations as vertically integrated and operating primarily within specific national institutional boundaries. Thus, both Dunlop's and Kochan, Katz and McKersie's frameworks fall short in their ability to explain how the strategies and practices of firms operating across national borders are affected by the multiple, and, at times, conflicting, national institutional environments in which they operate. Moreover, these frameworks do not help us understand how employment relations are affected by coordinating production (or services) across firms in a network, including the extent to which strategic choices and interactions in a nodal firm affect the strategies and practices of other firms in the network.

In contrast to these industrial relations frameworks, comparative institutional approaches emphasize the importance of distinct national institutional configurations which result in distinctive national capitalisms and in turn, structure firm strategies and practices, including those pertaining to employment relations. Whitley's (1999) framework focuses on differences between "national business systems", or systems of economic organization and control, based on the specific features of national institutional environments. Whitley argues that institutional contexts influence the particular characteristics of business systems, which give rise to 
distinctive national capitalisms. Accordingly, a national business system is established in a specific institutional context and the more integrated and mutually reinforcing the dominant institutions and their specific features are, the more coherent and distinctive the national business system will be. Distinctive national business systems and the institutional contexts in which they are created, in turn, have a substantial effect on the nature of firms, in terms of their governance characteristics and their organizational capabilities and the competitive strategies they pursue, and the ways in which they organize and control work.

The relationship between national institutions and firm strategies is also at the heart of the Varieties of Capitalism approach by Hall and Soskice (2001). According to Hall and Soskice, firms within a given national context "can perform some types of activities, which allow them to produce some kinds of goods, more efficiently than others because of the institutional support they receive for those activities in that political economy" (p. 37). The institutional configuration of national economies supports the use of specific modes of coordination and the adoption of particular competitive strategies which can, in turn, create distinct competitive advantages for firms competing in global markets. The authors distinguish between two broad "ideal types" of political economies: liberal market economies in which firms find institutional support for coordinating activities via arm's length market relations and coordinated market economies in which firms find institutional support for coordinating activities through collaborative non-market relationships. Each form of capitalism creates a different national level orientation. As such, each system creates different conditions under which firms can attain a competitive advantage.

Notwithstanding their usefulness in advancing our understanding of the employment relationship, especially cross-nationally, these comparative institutional frameworks have clear 
limitations. One of the strongest criticisms of the varieties of capitalism framework is that it assumes institutional stability despite the fact that national institutions are experiencing dramatic changes in the context of globalization and market liberalization (Hancke et al 2007; Jackson and Deeg 2006; Streeck and Thelen 2005). In addition, and particularly germane to this paper, although comparative institutional frameworks provide an advantage over traditional employment relations theories by helping us to understand how the connectedness within multinational firms across national boundaries affects firm (or "establishment") level employment relations systems (i.e. "home" vs. "host" country effects: Almond et al 2005; Edwards and Ferner 2002; Ferner 2000), they are much less useful for understanding how the

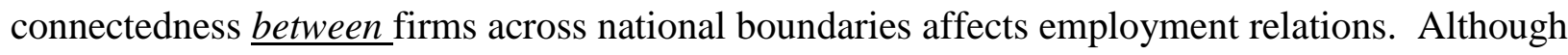
comparative institutional approaches do recognize the significance of inter-firm connections, for example by examining the extent of ownership and non-ownership coordination in business systems (Whitley 1999) or the level of inter-firm cooperation (Hall and Soskice 2001), these inter-firm connections are assumed to take place within national institutional boundaries and are defining features of distinctive national capitalisms.

Figure 1 graphically displays the contributions of the dominant employment relations frameworks reviewed here. As shown, national institutions and key actors and their external environments shape firm strategies at multiple levels (e.g. strategic, functional and workplace) which, in turn, structure the employment system inside the firm. Both sets of theories have gone a long way in highlighting firm strategies and employment relations within a single firm. They do not, however, focus on a key aspect of globalization - the integration of firms across national boundaries in cross-border production and service networks (e.g. global supply chains) and the employment relations outcomes of such interconnectedness. 


\section{INSERT FIGURE 1 HERE}

\section{Network-Based Approaches: Global Value Chains and Global Production Networks}

Network-based approaches, which take into account the changing nature of global production and in particular, the increasing prevalence and centrality of cross-border inter-firm relationships, exhibit the potential to overcome the limitations noted above. Two such approaches are global value chain (GVC) theory and the global production network (GPN) framework.

GVC theory came out of work in world-systems analysis by Hopkins and Wallerstein (1977; 1986) and was developed further by sociologist Gereffi and his colleagues using transaction cost economics, network theory and organizational learning. The building block of GVC theory is the notion of a commodity chain, defined by Hopkins and Wallerstein (1986: 159) as "a network of labor and production processes whose end result is a finished commodity", and later referred to as a "value chain", originally introduced by Porter (1985) and adopted by scholars such as Kaplinsky (1998) and Gereffi et al (2001) for its greater inclusiveness of network activities and products.

With the globalization of production and trade, firms have increasingly found themselves interacting with and within value chains that cross national and firm boundaries. Consequently, structures must be put in place to manage the complex intra- and inter-firm relationships which develop out of these global networks. The GVC framework seeks to better understand these relationships and more specifically, the governance structures used to coordinate them. In a seminal article, Gereffi, Humphrey and Sturgeon (2005) identify five main types of value chain configurations which can be differentiated based on their mode of governance: "market", 
"modular", "relational", "captive" and "hierarchy". These value chain configurations vary in their degree of explicit coordination and power asymmetry, with low levels of explicit coordination and power asymmetry in market-based configurations, high levels in vertically integrated hierarchical configurations and moderate to high levels of explicit coordination and power asymmetry in network configurations (modular, relational and captive). Three key variables determine the mode of governance or the choice of value chain configuration: the complexity of task requirements, the codifiability of those requirements and the capabilities of actual and potential suppliers in relation to the requirements. The higher the complexity of task requirements, the lower the codifiability of said requirements and the lower the capabilities of suppliers, the more likely that lead firms will choose value chain configurations that ensure high levels of explicit coordination and power asymmetry ${ }^{2}$. At the heart of GVC theory then is a configurational approach to global production that recognizes fundamentally different lead and supplier firm modes of coordination, interaction and interdependence.

The GPN framework, originating from the geography discipline, and typified by the approach of the "Manchester School", is also designed to capture the structure and dynamics of contemporary global production (Dicken et al 2001; Henderson et al 2002). This approach focuses on how companies manage their global operations. The three conceptual elements that drive GPN research are value (to estimate how and where value is captured in the network), power (how power is used in the capturing of this value) and embeddedness (the degree to which the network is territorially and consequently, socially and institutionally embedded). GPN researchers thus claim to be able to see how states, unions and a host of other actors and institutions influence the way global corporations organize their networks and the implications 
for industrial upgrading, value capture, poverty reduction, economic growth and a range of other outcomes.

Despite their value in advancing our understanding of the contemporary global economy, both of these approaches are not without their criticisms. GVC theory has been criticized for taking an overly narrow and static approach by emphasizing the governance of dyadic relations between lead and supplier firms within global value chains. Related to this is the view that the notion of a "chain" implies that production processes are vertical and linear when in reality vertical, horizontal and diagonal linkages make up complex “networks” (Henderson et al 2002: 442). A second criticism is that GVC theory ignores territory/space, unlike the GPN framework which looks at production networks as embedded in different geographic, institutional, political, and social contexts. In line with this, Taylor (2010) notes that the GPN framework captures global-local relations and restores the territoriality that GVC theory ignores.

In contrast, the GPN framework has been criticized for being too inclusive and all encompassing. Even proponents of the framework have noted the need for highly complex analyses, which most empirical studies to date have not been able to achieve (Coe et al 2008). This, in turn, has led some scholars to conclude that the GPN framework may be a "totalising theory lacking explanatory bite" (Taylor 2010: 251). Finally, both approaches are subject to the criticism that their central criteria are difficult to measure, although some case studies have been successful in using researcher judgment to identify the key variables in each framework and their implications for relationships in the network (e.g. Piore 2004).

While both approaches are associated with active research communities, and there is some crossover (see Barrientos, Gereffi and Posthuma 2011), there is a surprising absence of focus on labor and more specifically, workplace employment relations. Although scholars have 
increasingly called for integrating network-based approaches with the analysis of work and employment (e.g. Barrientos et al 2011; Rainnie et al 2011), studies to date have generally seen labor as one of a number of institutions to be examined (cf. Smith et al 2002), or have focused more specifically on labor agency in structuring global production networks/chains and vice versa (Bair and Ramsay 2003; Herod 2000; Hughes 2001; Rainnie et al 2011; Riisgaard and Hammer 2011; Taylor 2010). Other studies have used GVC/GPN approaches to examine the implications of global production networks for labor but have focused on limited aspects of work and employment, for example the increasing casualization and feminization of employment in such networks (Barrientos and Kritzinger 2004; Dolan and Sutherland 2003) or the implications of firm upgrading for labor (Barrientos, Gereffi and Rossi 2011; Knorringa and Pegler 2006). While a small number of these studies have also begun to examine the employment relations outcomes for workers at different points along the value chain, these tend to be country and industry-specific accounts and typically utilize a narrow range of criteria (e.g. wages, employment security), derived, in large part, from their analytical focus on the role of GVCs in poverty alleviation (see also Kabeer and Mahmud 2004; Nadvi and Thoburn 2004; also see Nadvi 2004 for a summary of these studies). An exception here is Wilkinson et al (2001) who explicitly focus on work organization and human resource management in global commodity chains but also continue the tradition of country and industry-specific case studies. The workplace has therefore not been the foci of most studies.

Given the employment relations field's focus on the workplace, we choose to use GVC theory as the basis for developing a new framework capable of capturing the effects of globalization on employment relations for several reasons. First, the specificity and narrow focus of GVC theory allow us to concentrate our attention on one key aspect of the global economy 
that traditional theories of employment relations do not permit, namely inter-firm relationships and the governance structures used to coordinate them. In addition, focusing on inter-firm linkages and their consequences for employment relations allows us to address a gap in both the GVC and GPN literatures - the treatment of the firm as a "black box", since global networks affect and are affected by what goes on inside interlinked firms (Coe et al 2008: 277). Second, using GVC theory to examine the employment relations implications of inter-firm relationships deals with the criticism that too much of prior GVC/GPN research has focused on lead firms and not suppliers (ibid.). Third, as we describe in more detail in the following sections, when our framework is combined with traditional strategic choice and comparative institutional perspectives of employment relations, our overall approach provides a comprehensive view of the factors that are likely to affect the structure and outcomes of employment relations systems at the firm level.

Using GVC theory, we argue that employment relations systems in global value chains need to be assessed on the basis of their specific configurations of firm interdependencies, task complexities and supplier capabilities. The different relationships and structures associated with different value chain configurations are, we maintain, essential for understanding employment relations across this increasingly important level of analysis. Different value chain configurations will lead to dramatically different employment relations strategies and outcomes.

GVC theory allows us to examine how interconnections within and between firms affect the employment relations processes and outcomes of connected firms. Since firms are typically interconnected across national boundaries, GVC theory also raises the possibility that we can examine the interaction between firms and different institutional environments throughout a given value chain ${ }^{3}$. GVC theory thus permits us to examine the dynamics of globalization and its 
effects on employment relations in firms at different levels in the value chain and in different countries simultaneously. In doing so, the GVC perspective shifts the focus from the firm within a national context to one that assesses the firm within the context of a global network, or in this case, value chain ${ }^{4}$.

In sum, in this article we build on the existing body of research that has recognized the importance of integration in global value chains for workers and labor more generally by providing an industry-neutral framework to explain the employment relations patterns associated with different international intra- and inter-firm relationships and their concomitant characteristics. In doing so, we use network approaches, and GVC theory in particular, to develop a broad framework for analyzing employment relations issues within and across global industries.

\section{A GVC-Based Configurational Framework for the Analysis of Employment Relations}

Building on GVC theory, we propose a new framework that examines the ways in which each value chain configuration, given its level of explicit coordination, power asymmetry and task requirements, shapes employment systems. Employment relations systems, according to this approach, are not only viewed as the product of national institutional variation and the strategic choices of key actors in response to different environmental pressures, but are also the result of different value chain configurations and the strategic interactions and institutional influences that characterize them.

Our framework is based on a number of important building blocks. First, value chain configuration is conceived as the coordination between two links (or firms) in a chain, for example the relationship between a lead firm and a supplier (Sturgeon 2009). As a result, each 
firm in a given value chain may have multiple, and perhaps differing, value chain configurations depending on the number of intra- and inter-firm relationships they have and no single configuration will likely characterize an entire chain.

Second, in our framework, lead firm is defined broadly and refers to the firm that is essentially driving the level and type of coordination between the two firms ${ }^{5}$. The lead firm might be a MNC and the value chain configuration may be reflecting the relationship between that MNC and a first-tier supplier or the lead firm could also be a first-tier supplier and the value chain configuration may be reflecting the relationship between that supplier and a subcontractor. The lead firm is the nodal firm in the chain.

Finally, since lead firms are responsible for driving value chain configurations, the framework presented here focuses on the employment systems of other firms in the network, namely suppliers rather than lead firms. As lead firms reduce direct ownership over activities and engage in value chains with supplier firms, the main effect in the lead firm is usually a decrease in the quantity of employment. However, since the underlying assumption of GVC theory is that lead firms externalize peripheral manufacturing and service activities and keep "core" activities in-house, we should not expect the quality or the structure and outcomes of employment systems in lead firms to necessarily be affected by their involvement in different value chain configurations with outside supplier firms ${ }^{6}$.

Figure 2 graphically depicts the configurational approach to employment relations and highlights the primary contribution of our framework to existing employment relations theory. Specifically, lead firm strategies, and strategic decisions over whether and what to make or buy in particular, determine the nature of task requirements. This leads to different interconnections between lead firms and suppliers (from market to hierarchy), with varying degrees of explicit 
coordination and power asymmetry, which, in turn, we argue, shape the employment systems of suppliers.

\section{INSERT FIGURE 2 HERE}

It is important to note that firm-level actors and their strategic choices and the national institutional contexts within which firms are embedded also play a role in structuring the employment relations systems of interconnected firms. A comparison of Figures 1 and 2 shows that these factors continue to play a significant role in shaping firm strategies and employment relations in both lead and supplier firms. In fact, the effects of national institutions and actor strategic choices may be central to value chain locational and configurational choices in the first place. For example, lead firm decisions over where to locate production are based, at least in part, on the nature of supplier firm national institutions, the availability of certain types of skills (which may be a function of strategic choices, national institutions or both) and the comparative advantages offered for given tasks in different locations (Kogut 1984; Ramirez and Rainbird 2010). Likewise, the role of states and of organized labor can be important determinants of initial locational decisions (Coe et al 2008; Smith et al 2002). This is evident, for instance, in developing countries where the economic development policies of states and the relative weakness of unions have allowed some large lead firms to engage in global labor arbitrage to minimize costs. In addition, the organization and mode of value chain governance may itself be shaped by the national institutional environments from which lead firms originate (Lane and Probert 2009) ${ }^{7}$. Nevertheless, our framework incorporates, and focuses attention on, the interconnections within and between firms in global networks and the ways in which these interconnections shape employment relations systems ${ }^{8}$. Taken together, we set forth the general 
proposition that different GVC configurations will lead to qualitatively different supplier employment relations systems.

Proposition 1: Each of the five GVC configurations will be associated with different supplier employment relations system characteristics.

Table 1 below specifies our configurational approach to studying employment relations. We delineate four specific dimensions that are influenced by each of the five GVC patterns. The first and second columns of Table 1 list the value chain configurations and the nature of task requirements under each configuration according to Gereffi and colleagues. The next four columns capture central criteria for understanding how the structure and outcomes of supplier employment relations systems are likely to vary across the five value chain configurations.

The first criterion, Lead Firm Influence on Supplier Employment Relations, refers to the role of lead firms in determining employment relations strategies and practices in supplier firms. An example here would be the role of lead firms in the training practices and organization of work in supplier firms. While lead firms can also influence supplier employment relations indirectly, for example through pressures to reduce costs, influence here refers to the direct involvement of lead firms in supplier employment relations systems. In this way, the level of lead firm influence also provides an indication of the degree of autonomy that suppliers have over their employment systems. In general, as lead firm influence increases, it is expected that supplier autonomy decreases and that suppliers will have less say over how their employment systems are structured. Second, Skill \& Knowledge of Employees in the Supplier Firm refers to the characteristics and capabilities of employees in the supplier firm and is strongly related to the nature of task requirements. For example, complex tasks will be associated with highly skilled workers while relatively simple tasks can be performed by less skilled workers. Third, Stability 
of Employment in the Supplier Firm refers to employment tenure and type and is related to the nature of tasks performed and the skill and knowledge of employees required to perform those tasks. Firms that perform tasks requiring basic skills that are easily learned by employees are more likely to have less stable and more flexible employment systems characterized by high attrition and/or a greater number of temporary workers because employees can be replaced with little investment of time and training. In contrast, firms that perform complex tasks that require higher skilled workers are much more likely to have stable employment systems characterized by long-term employment relationships and a greater proportion of permanent employees because replacing those employees will be much more difficult and costly. This is especially true where there is high firm specificity of skills and/or where firms have invested in training for skilled employees. Finally, National Institutional Influences on Supplier Employment Relations refers to the primary national institutions which shape supplier employment systems. As noted, employment strategies and practices are affected by the national institutional contexts within which firms are embedded. As firms operate across national boundaries, they are exposed to and influenced by multiple institutional environments. This includes institutions in their "home" country, the country from which they originate, as well as institutions in their "host" countries, the countries in which they operate. Likewise, firms in global production and service networks are also influenced by multiple institutional environments. For example, supplier firms in crossborder networks may be subject to national institutions from both their own home country, the country from which they originate and within which they often continue to operate, and national institutions from the lead firm's home country. The latter is especially likely in value chain configurations with high levels of explicit coordination and lead firm influence and may occur, for example, through the transfer of strategies and practices originating in and shaped by the 
national business system in the lead firm's home country to the supplier firm or through lead firm pressure on host country governments to adopt certain types of policies.

As shown in Table 1, the first three employment system criteria outlined range from low, moderate to high for each value chain configuration. The fourth, National Institutional Influences on Supplier Employment Relations, is labeled as "Local” where the supplier's employment system is influenced primarily by institutions from the supplier's home country, "Lead" where the supplier's employment system is influenced primarily by institutions from the lead firm's home country and "Local and Lead" where the supplier's employment system is influenced by institutions from both the supplier's home country and the lead firm's home country.

These criteria capture important dimensions of supplier employment relations systems that are likely to be affected by different GVC configurations. These criteria also allow us to highlight the mechanisms through which GVC configurations influence supplier employment relations systems. Thus, for example, we argue that different GVC configurations have different implications for the extent to which the lead firm has influence on the nature of supplier employment systems. Similarly, we maintain that each of the other criteria included in our framework represent central employment system factors that are likely to be influenced by the nature of the GVC configuration, thereby linking the mode of inter-firm coordination to intrafirm employment relations.

Two of the four employment system criteria used in the configurational framework, skill and knowledge of employees and stability of employment, are tangible, "objective" criteria that have been used in a wide variety of studies, including but certainly not limited to studies which employ GVC analysis, in order to understand different employment relations patterns (e.g. 
Storper and Salais 1997; Katz and Darbishire 2000; Dolan and Sutherland 2003; Barrientos and Kritzinger 2004; Nadvi 2004). Taken together, these criteria provide a nuanced portrait of the types of strategies and practices that may be utilized under different value chain configurations. For example, supplier firms in value chain configurations associated with higher skilled workers and greater employment stability are likely to be characterized by employment relations strategies and practices that enhance worker skills and increase commitment. In contrast, supplier firms in value chain configurations associated with low skilled employees and low employment stability will be less likely to invest in employment relations practices aimed at skill development and worker loyalty and more likely to adopt practices which minimize costs. The latter are also much more likely to operate on a nonunion basis.

The remaining two employment system criteria, lead firm and national institutional influences on supplier employment relations, represent dimensions of employment systems that are unique to connected firms. That is, while skill levels and employment stability capture standard elements of employment systems (whether integrated in value chains or not) that we expect to be affected by different value chain configurations, the other two proposed criteria are those that are only applicable to employment systems where a given firm has a relationship with another firm. These can be intra- or inter-firm relationships but the main idea is that the employment strategies and practices of a (supplier) firm are affected by their interaction with and connection to another (nodal) firm. We identify two key ways in which this may occur, both of which are likely to vary according to the nature of GVC configurations: through the direct involvement of a lead firm in the supplier firm's employment system and through institutional influences from the lead firm's home country. The latter dimension in particular recognizes the importance of different institutional environments in shaping employment relations within cross- 
border inter-firm arrangements, consistent with calls for greater attention to the "territorial embeddedness" of global production and service networks (e.g. Henderson et al 2001: 452) and for the need to better integrate global value chain/network approaches with comparative institutional perspectives (Lane and Probert 2009).

Accordingly, a GVC theory-based employment relations framework allows for a clear depiction of the tradeoffs associated with the different employment system configurations that cross-border connections within and between firms bring about. A comparison of each GVC configuration across the dimensions examined in this paper points to fundamentally different employment system ramifications. Next, we briefly review the characteristics of each value chain configuration, as outlined by Gereffi et al (2005), and their implications for supplier employment relations systems.

\section{INSERT TABLE 1 HERE}

\section{Elaboration of the Configurational Framework}

\section{Market Value Chain Configurations}

Market value chain configurations are those in which customers or lead firms and suppliers buy and sell standard products. Tasks are relatively simple and easily codified and suppliers have the capability to make products with little input from customers so there is low explicit coordination and low power asymmetry between lead firms and suppliers. Examples of a market value chain configuration can be found in the world bicycle industry, where lead firms and suppliers have an arm's-length contracting relationship and national bicycle brands purchase basic component parts produced according to international standards from specialized suppliers located in different parts of the world (Galvin and Morkel 2001). 
Given the nature of task requirements in the market value chain configuration, we would expect lead firm influence over supplier employment systems to be low, with suppliers retaining full control over employment strategies and practices. Since task complexity is low, we would also expect employees in the supplier firm to be low skilled which would, in turn, be associated with low employment stability in the form of higher attrition and temporary or casual employment. Finally, because coordination between the lead firm and the supplier firm are low, we would expect that the primary institutional influences will be local - that is, institutions in the supplier firm's home country or country of operation. Such employment relations systems are evident, for example, in the production segments of horticulture value chains where South African fruit growers employ low skilled workers and provide low employment stability through the increasing use of contract labor (Barrientos and Kritzinger 2004). Although lead firms exert indirect pressures on the employment strategies of these suppliers (e.g. through production imperatives and codes of conduct), they are not directly involved in determining employment strategies and practices in supplier firms and as a result, supplier firms have some degree of autonomy and "strategic choice" over how their employment systems are structured. Thus, we set forth the following proposition:

Proposition 2: Market value chain configurations will, compared to other GVC configurations, be associated with supplier employment relations systems that are characterized by low levels of lead firm influence, high levels of local institutional influence, low workforce skill levels, and low levels of employment stability. 


\section{Modular Value Chain Configurations}

Modular value chain configurations are characterized by "turn-key" suppliers who make products and services according to customer specifications. Although transactions are more complex than those found in market value chain configurations, they are also easily codified and suppliers have the capability to provide full packages and modules, using generic machinery to spread risk and capacity over a wide range of customers, so that explicit coordination and power asymmetry between the lead firm and the supplier remains low. Examples of modular value chain configurations can be found in the American electronics industry where globally operating supplier firms ("contract manufacturers") receive highly formalized specifications for productlevel manufacturing from U.S. lead firms (brand name electronics firms) and are responsible for purchasing required component parts and performing a range of services, including redesign-formanufacturability, circuit-board layout, testing, final product assembly, final packaging, and after-sales service (Sturgeon 2002).

Similar to the market value chain configuration, high supplier competence and low explicit coordination and power asymmetry between lead firms and supplier firms in the modular value configuration means that suppliers will retain full control over their employment systems with very little to no input from lead firms. Likewise, institutional influences on employment relations strategies and practices in the supplier firm will be primarily local. In contrast to the market value chain configuration however, the complex yet codifiable nature of tasks will result in moderately skilled workers capable of performing tasks according to detailed specifications and a moderately stable employment system with less (though still present) turnover and a higher (though still small) proportion of core employees. Evidence of such employment relations systems can also be found in horticulture value chains where pack-house workers involved in 
higher value-added tasks, such as preparing, processing and packaging fresh fruits and vegetables, are higher skilled and have better conditions of work (e.g. higher wages, formal employment contracts) than workers performing low value-added tasks on farms (Dolan 2004;

Dolan and Sutherland 2003). Nevertheless, like their counterparts on farms, these workers are generally low skilled and experience low employment stability as many are employed via "nonstandard" work arrangements such as casual and seasonal/temporary employment. Thus, we set forth the following proposition:

Proposition 3: Modular value chain configurations will, compared to other GVC configurations, be associated with supplier employment relations systems that are characterized by low levels of lead firm influence, high levels of local institutional influence, moderate workforce skill levels, and moderate levels of employment stability.

\section{$\underline{\text { Relational Value Chain Configurations }}$}

Relational value chain configurations are those in which interaction and communication between lead firms and suppliers is both frequent and central. Tasks are complex and not easily codified but suppliers are highly capable and provide lead firms with an incentive to outsource to gain access to complementary competencies. The need to exchange tacit knowledge results in high explicit coordination between lead firms and suppliers and a high degree of mutual dependence which is regulated through trust, reputation, deep social ties and often, though not always, spatial proximity. Examples of relational value chain configurations can be found in the global automotive industry where high product complexity combined with low codifiability and the absence of industry-wide standards have resulted in close collaboration, in the form of frequent interpersonal interaction and the transfer of tacit knowledge (i.e. proprietary standards), between lead firms and suppliers who have increasingly taken on a role in co-designing complex parts and subsystems (Sturgeon, Van Biesebroeck and Gereffi 2008). Subcontracting in the 
software industry and the offshoring of research and development in the life sciences and engineering design are additional examples of relational value chain configurations (Kuruvilla and Ranganathan 2008).

The nature of task requirements and relationships in relational value chain configurations are likely to give rise to employment systems which are jointly influenced by lead firms and suppliers. While lead firms are likely to play a significant role in supplier employment systems, for example with regards to training, suppliers will also retain a high level of control over how their employees are managed. Since tasks are both complex and uncodifiable, it is expected that employees will be highly skilled and knowledgeable and that employment systems will be highly stable, with low attrition and long-term employment relationships. Finally, because there is a high degree of mutual dependence between the lead firm and the supplier, we would expect that institutional influences on employment relations will be both local and lead, reflecting institutions from both the supplier's home country and the lead firm's home country. As we discuss in more detail later on, support for this employment relations system configuration can be found in the software industry where workers in supplier firms are highly skilled and work closely with, and in some cases even in the same country as, the lead firm (Piore 2004). Thus, we set forth the following proposition:

Proposition 4: Relational value chain configurations will, compared to other GVC configurations, be associated with supplier employment relations systems that are characterized by moderate levels of lead firm influence, dual lead and local institutional influence, high workforce skill levels, and high levels of employment stability.

\section{Captive Value Chain Configurations}

Captive value chain configurations are characterized by transactionally dependent suppliers. Tasks are highly complex and codifiable but because suppliers have low capabilities, they are provided with detailed instructions, rely on lead firms for resources, perform a narrow 
range of tasks, such as simple assembly, and are subject to high levels of monitoring and control by lead firms seeking to lock-in suppliers they have invested in. As a result, there is high explicit coordination and power asymmetry between lead firms and suppliers and suppliers encounter significant switching costs, thus making them "captive". Examples of captive value chain configurations can be found in food industries such as chicken where lead firms ("integrators") exert significant control over suppliers (independent farmers, referred to as "growers") who are responsible for raising the chickens and are dependent on integrators for market access and key inputs, including baby chicks, feed, medication and technical assistance (Gereffi, Lee and Christian 2009). A variety of firms in a variety of other industries (e.g. law, accounting) often have "captive" business process units or back offices in other countries that are also examples of this type of value chain configuration.

Given the high degree of dependence of suppliers on lead firms in captive value chain configurations, lead firm influence over supplier employment systems is expected to be high, especially with regards to training. Moreover, since suppliers perform a narrow range of tasks, employees will be relatively low skilled and employment systems will reflect a low level of stability, with high attrition and few permanent employees. Lastly, since there is high explicit coordination between the lead firm and the supplier, we should expect institutions from the lead firm's home country to influence employment relations in the supplier firm. At the same time however, comparative advantages offered by institutions in the supplier's home country may have been a deciding factor in choosing the supplier and the value chain configuration in the first place and as a result, local institutions will likely also be relevant. Such supplier employment relations systems are evident in the consumer electronics sector where Malaysian assembly plants are dependent on Japanese lead firms for high value-added activities (e.g. detailed product 
and process designs) and employ low skilled workers with little job security (Wilkinson et al 2001). High turnover is also the norm in these plants. Thus, we set forth the following proposition:

Proposition 5: Captive value chain configurations will, compared to other GVC configurations, be associated with supplier employment relations systems that are characterized by high levels of lead firm influence, dual lead and local institutional influence, low workforce skill levels, and low levels of employment stability.

\section{Hierarchical Value Chain Configurations}

Hierarchical value chain configurations refer to the relationships between lead firms and their vertically integrated subsidiaries. Tasks are highly complex and uncodifiable and because highly competent suppliers cannot be found outside the firm, these tasks are kept in-house ${ }^{9}$.

Since these tasks are often key to the lead firm's competitive advantage and require the exchange of tacit knowledge, there is high explicit coordination and power asymmetry between the lead firm and the subsidiary. Examples of hierarchical value chain configurations can be found in the relationships between large MNCs in a variety of industries, such as IT, and their subsidiaries involved in strategic functions such as core R\&D (Quan and Chesbrough 2010).

Given the highly complex and integral nature of tasks in hierarchical value chain configurations, lead firm influence over employment systems will be high and take place primarily via managerial control. Moreover, employees will be highly skilled and employment systems will be highly stable with low attrition and long-term employment. Finally, because the supplier is in-house and is often located close to the lead firm's headquarters, institutional influences are expected to be predominantly from the lead firm's home country. The consumer electronics sector also provides evidence of such employment systems in the domestic operations of large Japanese lead firms, where workers involved in complex, high value-added activities, 
such as design and development, are highly skilled specialists and have high job security

(Wilkinson et al 2001). In addition, since these plants and the lead firms are located in the same place, institutional influences on employment relations are primarily from the lead firm's home country - Japan. Thus, we set forth the following proposition:

Proposition 6: Hierarchical value chain configurations will, compared to other GVC configurations, be associated with supplier employment relations systems that are characterized by high levels of lead firm influence, high levels of lead institutional influence, high workforce skill levels, and high levels of employment stability.

\section{Summary}

In general, the configurational framework predicts that value chain configurations with highly complex and uncodifiable tasks, and thus moderate to high levels of explicit coordination and power asymmetry, will be characterized by supplier employment relations systems with relatively high levels of lead firm influence, high workforce skill levels, high employment stability and higher levels of lead institutional influence. In contrast, value chain configurations with comparatively simple and codifiable tasks, and thus low levels of explicit coordination and power asymmetry, will be characterized by supplier employment relations systems with relatively low levels of lead firm influence, lower workforce skill levels, lower employment stability and lower levels of lead institutional influence.

We provide examples from existing case studies to support the propositions of the configurational framework, where possible. However, as we noted earlier, much of the previous literature has only examined a narrow range of employment system criteria and case studies which have applied network-based approaches to the study of work and employment have disproportionately focused on one end, the "bottom" as Dolan (2004) calls it, of global value chains. Moreover, the use of different research questions and different perspectives (e.g. global 
commodity chains vs. global production networks) make it difficult to classify existing cases within the framework as most studies do not provide the level of detail necessary to do so.

In the next section, we further validate the configurational framework and demonstrate its utility for understanding the dynamics of globalization and its effects on employment relations through a brief analysis of three contemporary employment relations issues: outsourcing and its impact on employment relations, the centralization/decentralization of human resource strategies and practices in global networks, and the regulation of labor standards in global supply chains.

\section{Application of the Framework: Three Exemplars}

\section{Outsourcing and Employment Relations}

The international segmentation of production and services and the increasing vertical disintegration of MNCs have raised questions about outsourcing across national boundaries and its implications for employment relations. In particular, researchers have not only begun to question what can be outsourced but also what outsourcing means for both the quantity and quality of employment in supplier firms that are increasingly incorporated into global production and service networks (Batt, Holman and Holtgrewe 2009). Moreover, researchers have questioned whether and under what circumstances firm upgrading by suppliers leads to improvements in labor conditions (Barrientos, Gereffi and Rossi 2011; Knorringa and Pegler 2006).

By examining the nature of outsourced tasks in supplier firms and their place in crossborder networks, the configurational framework can provide us with a greater understanding of how outsourcing arrangements are likely to affect employment relations and the quality of employment in supplier firms. For instance, Table 1 would suggest that there will be differences 
in the nature and quality of employment relations among supplier firms in captive versus relational value chain configurations. While the close relationships between lead firms and supplier firms in both types of configurations would lead to high lead firm influence on employment relations and institutional influences from both the lead firm's home country and the supplier firm's home country, we would expect supplier firms in captive value chains to employ less skilled workers and have less stable employment systems than relational value chains where highly competent supplier firms will employ more skilled workers with high employment stability.

The outsourcing and offshoring of dedicated call centers is a primary example of a captive value chain configuration. Although there is variation, in general, call center work is seen as clerical work that is not central to a firm's core competencies (Doellgast, Batt and Sorensen 2009). Since the work is transactional and the requirements are easily codified, it is easy and perhaps even preferable to offshore call center work in order to reduce costs (Holman et al 2007, for example, estimate that labor costs make up 50-70\% of total costs in call centers). Research on call centers in developing economies has revealed that client (lead) firms tend to impose a standardized production model with Tayloristic, control-oriented characteristics on their supplier firms. Readily available call center technologies routinize work practices while electronic monitoring systems allow firms to monitor progress. The business strategies of the client firms drive the employment practices of the supplier firm. In order to provide better service to their American customers, lead firms devise training programs for offshore call center workers, including training in accent neutralization (e.g. US client firms have required Indian call center workers to speak with an American accent and use American names). Given the low cost model, the skill levels required of employees in supplier firms are generally low. High 
turnover in these firms is the rule rather than the exception and is taken as part of the costs of doing business. At the same time, employment characteristics in the call center conform to local laws and local institutional practices (Batt et al 2009). Batt and colleagues' research project also highlights differences in employment relations in call centers based on the institutional characteristics of the countries in which lead firms originate. In summary, consistent with the proposed characteristics of the captive value chain configuration outlined in Table 1, the outsourcing of call center work shows that lead firm influence on supplier firm employment practices is high, skill and knowledge levels of employees and employment stability in the supplier firm are low and institutional influences on supplier firm employment relations constitute a mix of lead and local.

In contrast, the offshoring of knowledge work, such as software development, represents a relational value chain configuration between lead and supplier firms with very different implications for employment relations. Lead firms have a high degree of influence on supplier employment relations, particularly in terms of the training of software programmers and analysts who have to work to quality standards established by the lead firm. Employees in supplier firms are generally highly skilled and well paid, which is also partially a function of the local institutional conditions and labor markets in which these firms are embedded. Over time, as Piore (2004) notes in his study of the software industry, the elements of integration and coordination in testing new software forces employees in lead firms and supplier firms to work together and have a shared vision of the software architecture. This interdependency between lead and supplier firms may, in turn, result in a gradual process of technical skills upgrading at the supplier firm. In this way, the strategies of the lead firm, and in some cases institutional influences from the lead firm's home country, have large consequences for employees of the 
supplier. This is evident, for example, in the case of Infosys, an Indian software company with over 1000 Indian employees located in the US whose conditions of work are influenced by both US and Indian laws.

Similarly, in his study of knowledge process offshoring, Jensen (2009) notes that the offshoring process deepens the relationship between client and subcontractor firms and the subcontractor firm gradually acquires the highly specialist knowledge of the client firm's structure, culture, processes and even core competencies. This may, in turn, result in "functional upgrading" wherein supplier firms engage in additional and higher value-added activities (Humphrey and Schmitz 2002) and is consistent with Gereffi et al's (2005) assertion that value chain configurations in a variety of different industries have evolved over time. As a result, we should expect to see differences in the employment systems of supplier firms as value chains evolve and the framework presented here can provide some idea of what we might expect to see. An example of this can be found in the automotive parts industry in India where a transition from assembly to design has resulted in higher skilled workers and greater employment stability in supplier firms (Nathan and Kalpana 2007), consistent with the employment relations implications of a shift from a modular or captive value chain configuration to a relational value chain configuration in our framework.

These examples clearly illustrate the usefulness of GVC theory and our configurational framework for the analysis of questions related to outsourcing and its impact on employment relations in supplier firms. As is evident in the call center and software development illustrations, the framework is particularly useful for comparative analysis, allowing us to examine the differential effects of outsourcing across supplier firms that perform significantly different tasks in different value chain configurations. The framework is also useful for understanding how 
supplier firm upgrading and changes in value chain configurations are likely to affect labor conditions in supplier firms over time. The latter also illustrates the dynamic and reciprocal nature of our configurational framework, which we discuss in more detail later on.

\section{Centralization/Decentralization of Human Resource Management in Global Networks}

Changes in the nature of international trade and economic organization have not only raised questions about the quality of employment in global networks but also questions related to the centralization vs. decentralization of human resource management in global networks and in particular, the extent and circumstances under which the human resource strategies and practices of lead firms will extend to suppliers (both in-house and external) in the larger network. To be sure, there are significant competing pressures for both the centralization and decentralization of human resource strategies and practices in global networks (Edwards and Kuruvilla 2005). A key pressure for centralization is the need for global human resource policies to be consistent with the global business strategies of the lead firm. Regional chains of excellence also require some degree of centralization or coordination. In addition, there is also the "country of origin" effect, where policies designed in the lead firm's headquarters get transferred to the firm's locations and suppliers in other countries, primarily because the "center of gravity" of corporate HR lies in the country of origin.

On the other hand, local isomorphic pressures in the form of legal, cultural and labor market institutions exert pressure for the decentralization of human resource management across the chain. The complexity of managing global workforces also exerts pressure to decentralize human resource systems. Furthermore, internal political dynamics also affect the extent to which centralization tendencies are seen as ways to extend the power and influence of corporate staff and resisted by local managers. Finally, the increasing stratification of production across 
national boundaries raises questions about the efficacy of a centralized approach to employment relations. Since different functions are often carried out across countries, lead firms may have little incentive to standardize practices across their international operations and may instead find it beneficial to tailor practices according to locations and tasks performed (e.g. see Wilkinson et al 2001). As such, it is not clear if and when lead firm human resource strategies and practices will extend to their global network.

The proposed framework can be used to help address questions regarding the extent and conditions under which the human resource strategies and practices of lead firms will extend beyond lead firm boundaries to suppliers around the world. For example, when will lead firms play a role in setting the practices of their suppliers? And what types of practices are most likely to be centrally determined? The answer to these questions will be based, in part, on the position of suppliers vis-à-vis large lead firms and the nature of task requirements in value chains. As mentioned previously for example, transformations in assembler-supplier relations have occurred in the auto industry as suppliers have taken on an increasing role in the design of automotive components and engage in just-in-time delivery systems (e.g. Nathan and Kalpana 2007;

Sturgeon et al 2008). Consistent with a more relational approach, the closer and more complex long-term relationships between lead firms and suppliers in the auto industry have, in turn, resulted in the centralization of training in the value chain with corporate HR in the lead firm designing training programs for workers in the supplier firm. And in some cases, relationships between lead and supplier firms have even involved the lead firm taking on responsibilities for the supplier firm's workforce. Similarly, where logistics companies such as UPS take on the responsibilities of distribution and customer service for their client firms such as Toshiba, UPS employees have to be trained in the Toshiba way of dealing with customers and hence, training 
becomes a centralized activity covering both Toshiba and UPS workers (Waters 2010). In the case of software development as well, client firms such as Microsoft and SAP devise training standards for workers in software offshoring firms (Jalote 2004).

The configurational framework thus provides a useful starting point for analyzing the centralization and decentralization of human resource management in global networks and in particular, the extent and circumstances under which lead firm strategies and practices will extend to their global network based on the nature of intra- and inter-firm relationships between lead firms and their suppliers.

\section{Managing Labor Standards in Global Supply Chains}

The increasing internationalization of production and services has also raised questions about when and how large MNCs, such as retailers and branded marketers, will play a role in monitoring labor conditions in the operations of their subcontractors around the world. In response to widespread media attention and coordinated campaigns by NGOs, consumer organizations and organized labor aimed at bringing attention to exploitative working conditions in factories supplying global brands, MNCs in a wide variety of industries have undertaken initiatives to improve labor standards in supplier firms. Corporate codes of conduct are one such example. Despite years of effort however, there is some question as to the efficacy of these initiatives as studies have revealed mixed results of corporate codes of conduct and monitoring efforts on working conditions and outcomes across firms in global supply chains (Locke, Qin and Brause 2007). The general lack of compliance with such codes has been linked to a large number of factors, including the capability of suppliers in meeting the standards laid down in corporate codes as well as how those standards have been spelled out. 
The configurational framework provides an analytical tool for examining the conditions under which public campaigns and union strategies will be most effective in persuading MNCs to undertake initiatives to improve labor standards and in understanding when such initiatives are likely to result in better working conditions in supplier firms. In particular, by understanding the role of suppliers in global value chains, scholars and practitioners can gain a better understanding of the nature of intra- and inter-firm relationships between MNCs and their suppliers, including the level and type of influence that MNCs have, and in turn, better structure strategies and initiatives to ensure success. For example, looking at Table 1, we might expect that public campaigns and union strategies targeting MNCs will be less effective in value chain configurations with low lead firm influence, such as in market and modular configurations. Furthermore, the effectiveness of MNC-driven initiatives to improve labor standards is also likely to be lower in these types of value chain configurations than in hierarchical, relational or even captive value chain configurations where lead firms have more control and leverage over suppliers and their employment systems. Recent research on labor strategies in global value chains and on supplier compliance with corporate codes of conduct reveals support for these propositions. For instance, in their analysis of labor strategies in the cut flower and banana industries, Riisgaard and Hammer (2011) show that campaigns to incorporate labor standards at the level of production were most successful when targeted at vertically integrated value chains and value chains where retailers had high levels of explicit coordination with suppliers rather than in value chains characterized by market coordination. Similarly, research on compliance with corporate codes of conduct reveal substantial variation in compliance levels and working conditions across supplier firms, which is due, at least in part, to the nature of relationships between MNCs and their suppliers. For example, Locke et al (2007) find that the categorization 
of a supplier firm as a "strategic partner" (defined as tier-one suppliers) and the number of visits by production specialists, which reflects the level of explicit coordination between Nike and its suppliers, are positively related to compliance with corporate codes of conduct.

In this section, we have presented three contemporary "cases" where a GVC-based perspective could enhance our understanding of global phenomena in ways that traditional approaches cannot. Although our description in each case is brief, it is illustrative of the potential of the configurational framework for enhancing our understanding of these topics.

\section{Capturing the Dynamics of the Configurational Framework: Implications for Firm Interconnectedness and Employment Relations}

The three examples above highlight the applicability of the proposed framework. They also, however, illustrate some of the complexity and reciprocal dynamics associated with a configurational approach to employment relations in a global context. As seen above, GVC configurations not only affect supplier employment relations systems, but may also, themselves, be affected by employment related dynamics and developments in these firms. Thus, this framework must also allow us to capture the reciprocal and dynamic effects associated with global firm interconnectedness. We have used GVC theory to build a framework which outlines the ways in which different value chain configurations, given the nature of their task requirements, level of explicit coordination and power asymmetry, shape supplier employment systems and show how the framework can be used to address a range of global employment relations issues. However, in presenting this framework, for the sake of parsimony, we have chosen not to focus on all of the dynamics of global value chains and inter-firm relations which are key to GVC theory and important for understanding both the formation and evolution of 
value chain configurations and employment relations systems. It is to these dynamics that we turn to next.

Figure 2 focuses on the manner in which lead firm strategies affect the formation of a given GVC configuration and the associated implications for supplier firm employment relations systems and strategies. This is a core and central component of our proposed framework. Nevertheless, one of the features of global interconnected relationships between lead and supplier firms is the inherently reciprocal relationship between these actors. More specifically, we argue that there are six main linkages in our framework in which these reciprocal dynamics play out. Figure 3, below, proposes this more nuanced version of our framework by highlighting the "dynamic" relationships between GVC actors' strategies, outcomes, and national institutional contexts.

\section{INSERT FIGURE 3 HERE}

First, although lead firm strategies play an important role in establishing the nature of the task requirements, it is also clear that the structural elements of a given global production system are also likely to influence the strategies employed by lead firms (1) in Figure 3). Changes in the nature of task requirements, such as the complexity and codifiability of tasks or supplier capabilities, will feedback into lead firm strategic decisions regarding what they will keep inhouse and what they will outsource ("make-or-buy" decisions) and ultimately back to the choice of value chain configuration. This is, in fact, a key premise of GVC theory and was evident, for example, in Gereffi et al's (2005) case study of the apparel industry where increasing supplier competence in East Asia resulted in suppliers shifting from simple assembly in captive value chain configurations to full package production in relational value chain configurations (p. 92). 
Second, central to our proposed framework is the argument that different GVC configurations influence supplier firm employment systems. Nevertheless, as described above, supplier firm employment relations dimensions have clear implications for lead firm strategies as well, which, in turn, influence GVC configurations. Thus, we propose a reciprocal relationship between supplier firm employment systems and lead firm strategies (2) in Figure 3). Changes in the nature of employment systems of supplier firms can, therefore, affect the strategic positioning of lead firms. This can occur directly or indirectly through the influence of supplier firm employment system dimensions on the nature of task requirements, as illustrated in the above example of increasing supplier competence in the apparel industry. This is important since it accounts, in part, for the manner in which global production relationships may change and evolve over time.

Third, Figure 3 also proposes a reciprocal relationship between supplier firm strategies and supplier firm employment systems (3) in Figure 3). Consistent with traditional employment relations theories, our configurational framework recognizes the role of supplier firm strategies, influenced by national institutions and the strategic choices of actors in response to environmental pressures, in shaping the employment relations systems of supplier firms. Nevertheless, supplier firm employment systems, which, we argue, are also a function of different GVC configurations, are also likely to be a central component in shaping supplier firm strategies. This may occur, for instance, where interaction in global value chains brings about changes in supplier employment system dimensions, such as skill and knowledge levels, which cause suppliers to rethink and revise their strategies and tasks performed. In fact, this is one of the ways in which firm upgrading by suppliers can take place in global value chains and our 
discussion in the previous section of lead and supplier firm relationships in the software industry provides a clear illustration of this.

Fourth, Figure 3 highlights the reciprocal relationship between lead firm strategies and supplier firm strategies (4) in Figure 3). Building on the logic of reciprocal interconnected global relationships, it is proposed that supplier firm strategies will influence the strategic posture adopted by lead firms and that lead firm strategies will also have a direct effect on the strategies employed by the supplier firm. Thus, supplier firm strategies will likely influence lead firm strategic decisions, particularly those pertaining to the make-or-buy decision, and lead firm strategies will, in turn, structure supplier firm strategic decisions, particularly over time as the lead firm and supplier firm continue to work together. This may include, for example, decisions over what lines of business to be in as well as decisions over employee development to meet strategic needs.

Fifth, our framework accounts for lead and supplier firm national institutions. We argue that lead and supplier firm national institutions are central to their respective strategies. Here too, however, the very interconnectedness of the GVC relationship implies that the national institutional context of supplier firms are likely to influence the strategies employed by lead firms and that lead firm strategies will also, in turn, affect supplier firm national institutional systems. Thus, we propose a reciprocal relationship between lead firm strategies and supplier firm national institutions (5) in Figure 3). As initially discussed in the presentation of our configurational framework, supplier firm national institutions may affect lead firm strategic decisions over whether and what to make or buy as well as decisions over where to locate production. At the same time, lead firm strategies may also influence supplier firm national institutions. One way that this can occur is through lead firm pressure on host country 
governments to adopt (or disregard) certain policies. Indeed, since the economic development strategies of many countries have been predicated on being part of selected global value chains (e.g. Malaysia in semiconductors, Cambodia in garments), lead firms often have substantial influence over host country governments. In Malaysia, for instance, foreign investors were successful in getting exemptions to overtime laws and in creating a ban on trade unions in the semiconductor sector in the 1970s and 1980s (Kuruvilla 1996).

Accordingly, the final reciprocal relationship we identify in Figure 3 is that between supplier firm actors, especially "non-firm" actors such as states and labor, and lead firm strategies (@) in Figure 3). The actions of host country governments and trade unions can affect lead firm strategic decisions over the organization and location of production. The absence or weakness of unions in a given host country, for example, may be key to attracting lead firm investment. Lead firm strategies can also serve to weaken unions or other forms of worker representation, as the above example in the Malaysian context shows. On the other hand, "strong" states and labor can also be highly effective in influencing lead firm strategies and in turn, GVC configurational choices. This is evident in automobile production networks in China where the government has played a significant role in determining the entry of foreign firms and the form that such entry can take (Coe et al 2008). Similarly, studies of labor agency have shown that the actions of supplier firm workers and unions can shape the structure and operation of global value chains (Rainnie et al 2011).

Taken together, we argue that global value chains are not static and the formation and evolution of chains is not linear. Central to the interconnectedness of global value chains is the reciprocal and dynamic relationships between firms. This means that a multitude of supplier and lead firm factors affect configurational choices and this, in turn, has implications for the structure 
and outcomes of employment relations systems in the chain. Changes in value chain configurations over time will be associated with changes in supplier employment relations and, as our example in the previous section of firm upgrading in the auto industry illustrates, the configurational framework presented in Table 1 can provide an idea of the direction and shape of such change.

\section{Conclusion}

The key contribution of this paper has been to present a new framework that builds on and extends the utility of GVC theory in explaining employment relations in firms linked across the global economy. Focusing on the value chain as the level of analysis leads to the identification of multiple configurations that operate simultaneously across national and firm boundaries. Each value chain configuration, we argue, has different implications for employment relations processes and outcomes. Our framework permits us to understand and analyze these implications in ways that current theories of employment relations do not allow. It also provides researchers with a set of testable propositions and a baseline tool for comparative analysis. It should be noted that some scholars have argued that the GVC framework has received limited empirical support due, in part, to the difficulties of measuring its core criteria. By outlining a set of testable propositions examining four clear employment relations criteria, our framework provides for a defined context in which to empirically test the utility of the GVC framework as well.

The configurational framework presented in this paper is by no means a complete theory of employment relations. Instead, our framework allows us to take into account a defining element of the global economy - international intra- and inter-firm relationships and their consequences for supplier employment relations. In this way, our intent and approach is 
analogous to that of GVC theory. As Sturgeon (2008: 133) notes, the GVC framework accounts for the characteristics which are likely to give rise to different patterns of global value chain governance, absent other influences. If a pattern of governance does not fit the theory, then another factor may be at work. Likewise, the configurational framework outlines the manner in which different value chain configurations will structure employment systems in supplier firms, all other things equal. If an employment relations pattern does not fit the framework, it may be that other factors, such as national institutions or the strategic choices of actors, are at play. Thus, the configurational framework serves as a complement to previous employment relations theories and when used in combination with such theories, allows us to better understand and account for the variety of factors which have the potential to shape employment relations systems at the firm level.

Future research needs to examine the utility of this framework via both further validation and further development. A key first step in validation would be empirical comparisons of our framework across different value chain configurations. Also, while we examine the role of national institutional influences on employment relations across different value chain configurations, one key area of development would be a greater integration of institutional approaches in ways that allow scholars to simultaneously examine the interaction between firms and between firms and different institutional environments. In addition, although our approach recognizes the importance of institutional influences, the focus has mainly been on national institutions. Another possibility for future research is to examine and incorporate the implications of other institutional influences, such as the soft law approaches of supra-national institutions like the ILO and WTO. Finally, while our proposed framework follows the lead of Gereffi et al's GVC theory by focusing on particular links in a global network or value chain 
(namely the relationship between a given lead firm and supplier), more work is needed to understand how relationships in one part of the chain affect relationships in other parts of the chain (Bair 2009). Moreover, since each firm in a given value chain may have a number of intraand inter-firm relationships, additional research is needed to understand how employment relations systems are affected by participation in multiple, and different, value chain configurations. Thus, empirical testing of our framework should examine the extent to which a firm's different value chain configurations interact in affecting the proposed employment system criteria.

In sum, our framework shifts the focus of employment relations analysis away from the individual firm within a given national context to the global networks in which they belong. In so doing, the framework provides employment relations scholars with a new lens for understanding employment relations in the global economy.

\section{References}

Almond, P., Edwards, T., Colling,T., Ferner, A., Gunnigle, P., Muller-Camen, M., Quintanilla, J. and Wachter, H. (2005). 'Unraveling home and host country effects: an investigation of the HR policies of an American multinational in four European countries'. Industrial Relations, 44 (2): 276-305.

Bair, J. and Gereffi, G. (2001). 'Local clusters in the global chain: the causes and consequences of export dynamism in Torreon's blue jeans industry'. World Development, 29 (11): 1885-1903.

Bair, J. and Ramsay, H. (2003). 'MNCs and global commodity chains: implications for labor strategies'. In W. N. Cooke (ed.), Multinational Companies and Global Human Resource Strategies. London: Quorum Books.

Bair, J. 2009. 'Global commodity chains: genealogy and review'. In Jennifer Bair (ed.), Frontiers of Commodity Chain Research. Stanford, CA: Stanford University Press, pp. 1-34.

Barrientos, S., Gereffi, G. and Posthuma, A (Guest Editors). (2011). 'Special Feature: Decent Work in Global Production Networks'. International Labour Review, 150(3-4). 
Barrientos, S., Gereffi, G. and Rossi, A. (2011). 'Economic and social upgrading in global production networks: a new paradigm for a changing world'. International Labour Review, 150(3-4): 319-340.

Barrientos, S., Mayer, F., Pickles, J. and Posthuma, A. (2011). 'Decent work in global production networks: framing the policy debate'. International Labour Review, 150(3-4): 299317.

Barrientos, S. and Kritzinger, A. (2004). 'Squaring the circle: Global production and the informalisation of work in South African fruit exports'. Journal of International Development, 16: 81-92.

Batt, R, Holman, D. and Holtgrewe, U. (2009). 'The globalization of service work: Comparative institutional perspectives on call centers'. Introduction to a Special Issue of Industrial and Labor Relations Review, 62 (4): 453-88.

Boyer, R. (1988). The Search for Labour Market Flexibility: The European Economies in Transition. Clarendon Press: Oxford.

Coe, N.M., Dicken, P. and Hess, M. (2008). 'Global production networks: realizing the potential. Journal of Economic Geography, 8 (3): 271-295.

Dicken, P., Kelly, P.F., Olds, K. and Yeung, H. W-C. (2001) 'Chains and networks, territories and scales: towards a relational framework for analysing the global economy'. Global Networks, 1(2): 89-112.

Doellgast, V., Batt, R. and Sorensen, O. H. (2009). 'Introduction: institutional change and labor market segmentation in European call centers'. European Journal of Industrial Relations, 15 (4): 349-371.

Dolan, C.S. (2004). 'On Farm and Packhouse: Employment at the Bottom of a Global Value Chain’. Rural Sociology, 69(1): 99-126.

Dolan, C.S. and Sutherland, K. (2003). 'Gender and employment in the Kenya horticulture value chain'. Globalisation and Poverty Discussion Paper 8.

Dunlop, J. (1958). Industrial Relations Systems. New York: Holt.

Edwards, T. and Ferner, A. (2002). 'The renewed 'American challenge': a review of employment practice in U.S. multinationals'. Industrial Relations Journal, 33: 94-110.

Edwards, T. and Kuruvilla, S. (2005). 'International HRM: national business systems, organizational politics and the international division of labour in MNCs'. International Journal of Human Resource Management, 16 (1): 1-21. 
Ferner, A. (2000). 'The embeddedness of US multinational companies in the US business system: Implications for HR/IR'. Leicester Business School Occasional Paper 61.

Galvin, P. and Morkel, A. (2001). 'The effect of product modularity on industry structure: the case of the world bicycle industry'. Industry and Innovation, 81: 31-47.

Gereffi, G. (1995). 'Global production systems and third world development'. In B. Stallings (ed.). Global Change, Regional Response: The New International Context of Development. Cambridge, UK: Cambridge University Press, pp. 100-142.

Gereffi, G., Humphrey, J., Kaplinsky, R., and Sturgeon, T. (2001). 'Introduction: globalisation, value chains, and development'. IDS Bulletin, 32(3): 1-8.

Gereffi, G., Humphrey, J. and Sturgeon, T. (2005). 'The governance of global value chains'. Review of International Political Economy. 12 (1): 78-104.

Gereffi, G, Lee, J. and Christian, M. (2009). 'U.S.-based food and agricultural value chains and their relevance to healthy diets'. Journal of Hunger \& Environmental Nutrition, 4 (3\&4): $357-$ 374.

Hancke, B. M., Rhodes, M. and Thatcher, M. (2007). 'Introduction: beyond varieties of capitalism'. In B. Hancke, M. Rhodes, and M. Thatcher (eds.). Beyond Varieties of Capitalism: Conflict, Contradiction, and Complementarities in the European Economy. Oxford: Oxford University Press, pp. 3-38.

Hall, P. A. and Soskice, D. (2001). Varieties of Capitalism: The Institutional Foundations of Comparative Advantage. Oxford: Oxford University Press.

Henderson, J., Dicken, P., Hess, M., Coe, N. and Yeung, H, W-C. (2002). 'Global production networks and the analysis of economic development'. Review of International Political Economy, 9 (3): 436-464.

Herod, A. (2000). 'Implications of Just-in-Time Production for union strategy: lessons from the 1998 General Motors-United Auto Workers dispute'. Annals of the Association of American Geographers, 90(3): 521-547.

Holman, D., Batt, R. and Holtgrewe, U. (2007). The Global Call Center Report: International Perspectives on Management and Employment. Ithaca, NY: Authors.

Hopkins, T. K. and Wallerstein, I. (1977). 'Patterns of development of the modern worldsystem'. Review, 1(2): 11-145.

Hopkins, T. K. and Wallerstein, I. (1986). 'Commodity chains in the world economy prior to 1800'. Review, 10(1): 157-70. 
Hughes, A. (2001). 'Multi-stakeholder approaches to ethical trade: towards a reorganization of UK retailers' global supply chains?’ Journal of Economic Geography, 1(1): 421-437.

Humphrey, J. H. and Schmitz, H. (2002). 'How does insertion in global value chains affect upgrading in industrial clusters?’ Regional Studies, 36 (9): 1017-1027.

Jackson, G. and Deeg, R. (2006). 'How many varieties of capitalism? Comparing the comparative institutional analyses of capitalist diversity'. MPIfG Discussion Paper. Germany: Max-Planck Institute for the Study of Societies.

Jalote, P. (2004). 'CMM in practice: process for executing software projects at Infosys'. SEI Series in Software Engineering. Addison-Wesley.

Jensen, P. D. O. (2009). 'A learning perspective on the offshoring of advanced services'. Journal of International Management, 15 (2): 181-193

Kabeer, N. and Mahmud, S. (2004). 'Globalisation, gender and poverty: Bangladeshi women workers in export and local markets'. Journal of International Development, 16(1): 93-109.

Kaplinsky, R. (1998). 'Globalization, Industrialisation and Sustainable Growth: The Pursuit of the Nth Rent'. IDS Discussion Paper \#365. Institute of Development Studies, University of Sussex.

Knorringa, P. and Pegler, L. (2006). 'Globalisation, firm upgrading and impacts on labour'. Journal of Economic and Social Geography, 97 (5): 470-479.

Kochan, T. A. Katz, H. C. and McKersie, R. B. (1986). The Transformation of American Industrial Relations. New York, NY: Basic Books.

Kogut, B. (1984). 'Normative observations on the international value-added chain and strategic groups'. Journal of International Business Studies, 15 (2): 151-167.

Kuruvilla, S. and Ranganathan, A. (2008). 'Economic development strategies and macro- and micro-level human resource policies: the case of India's 'outsourcing' industry'. Industrial and Labor Relations Review, 62 (1): 39-72.

Kuruvilla, S. (1996). 'Industrialization strategies and national industrial relations policy in Southeast Asia: Singapore, Malaysia, Philippines, and India'. Industrial and Labor Relations Review, 49 (4): 635-657.

Lane, C. (2008). 'National capitalisms and global production networks: an analysis of their interaction in two global industries'. Socio-Economic Review, 6: 227-260.

Lane, C. and Probert, J. (2009). National Capitalisms, Global Production Networks. Oxford: Oxford University Press. 
Locke, R. M., Qin, F. and Brause, A. (2007). 'Does monitoring improve labor standards? Lessons from Nike'. Industrial and Labor Relations Review, 61 (1): 3-31.

Nadvi, K. (2004). 'Globalisation and Poverty: How can Global Value Chain Research Inform the Policy Debate?' IDS Bulletin, 35(1): 20-30.

Nadvi, K. and Thoburn, J. (2004). 'Vietnam in the global garment and textile value chain: impacts on firms and workers'. Journal of International Development, 16(1): 111-123.

Nathan, D. and Kalpana, V. (2007). 'Issues in the Analysis of Global Value Chains and Their Impact on Employment and Incomes in India'. ILO Discussion Paper Series No. 183. Geneva: International Institute for Labor Studies.

Piore, M. J. (2004). 'The limits of the division of labor in design and the prospects for off-shore software development in Mexico'. Prepared for The Software Industry in the Developing World Workshop, Yale University.

Piore, M. J. and Sabel, C. F. (1984). The Second Industrial Divide: Possibilities for Prosperity. New York: Basic Books.

Porter, M. E. (1985). Competitive Advantage: Creating and Sustaining Superior Performance. New York: The Free Press.

Quan, X. and Chesbrough, H. (2010). 'Hierarchical segmentation of R\&D process and intellectual property protection: evidence from multinational R\&D laboratories in China'. IEEE Transactions on Engineering Management, 57 (1): 9-21.

Rainnie, A., Herod, A. and McGrath-Champ, S. (2011). 'Review and positions: global production networks and labour'. Competition and Change, 15(2): 155-169.

Ramirez, P. and Rainbird, H. (2010). 'Making the connections: bringing skill formation into global value chain analysis'. Work, Employment and Society, 24 (4): 699-710.

Riisgaard, L, and Hammer, N. (2011). 'Prospects for labour in global value chains: labour standards in the cut flower and banana industries'. British Journal of Industrial Relations, 49 (1): 168-90.

Robinson, P.K. and Rainbird, H. (2011). 'Beyond the organisation and the nation state... and the employment relationship, same as it ever was? Global value chains and the challenges for industrial relations research'. Paper presented at BJIR 50 ${ }^{\text {th }}$ Anniversary Conference, Across Boundaries: An Interdisciplinary Conference on the Global Challenges Facing Workers and Employment Research.

Schonfield, A. (1965). Modern Capitalism: The Changing Balance of Public and Private Power. Oxford: Oxford University Press. 
Smith, A., Rainnie, A., Dunford, M., Hardy, J., Hudson, R. and Sadler, D. (2002). 'Networks of value, commodities and regions: reworking divisions of labour in macro-regional economies'. Progress in Human Geography, 26(1): 41-63.

Streeck, W. and Thelen, K. (2005). 'Introduction'. In W. Streeck and K. Thelen (eds.), Beyond Continuity: Institutional Change in Advanced Political Economies. Oxford: Oxford University Press, pp. 1-39.

Sturgeon, T.J. (2002). 'Modular production networks: a new American model of industrial organization.' Industrial and Corporate Change, 11 (3): 451-496.

Sturgeon, T. J. (2009). 'From commodity chains to value chains: interdisciplinary theory building in an age of globalization'. In J. Bair (ed.), Frontiers of Commodity Chain Research. Stanford, CA: Stanford University Press, pp. 110-135.

Sturgeon, T., Van Biesebroeck, J. and Gereffi, G. (2008). 'Value Chains, Networks and Clusters: Reframing the Global Automotive Industry'. Journal of Economic Geography, 8 (3): 297-321.

Taylor, P. (2010). 'The Globalization of service work: analysing the transnational call centre value chain'. In P. Thompson and C. Smith (eds.). Working Life: Renewing Labour Process Analysis. Basingstoke: Palgrave Macmillan, pp. 244-268.

Waters, D. (2010). Global Logistics: New Directions in Supply Chain Management. Kogan Page Publishers: London and New York.

Whitley, R. (1999). Divergent Capitalisms. Oxford: Oxford University Press.

Wilkinson, B., Gamble, J., Humphrey, J., Morris, J. and Anthony, D. (2001). 'The New International Division of Labour in Asian Electronics: Work Organization and Human Resources in Japan and Malaysia'. Journal of Management Studies, 38(5): 675-695. 


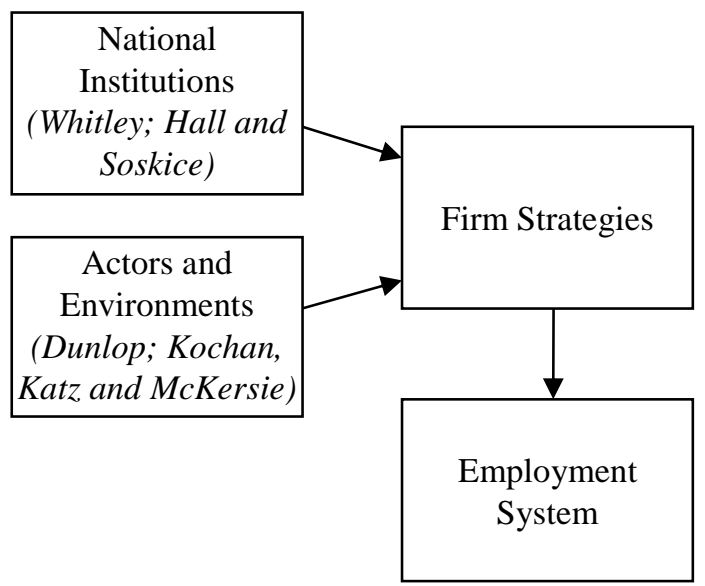

Figure 1: Dominant Employment Relations Frameworks 


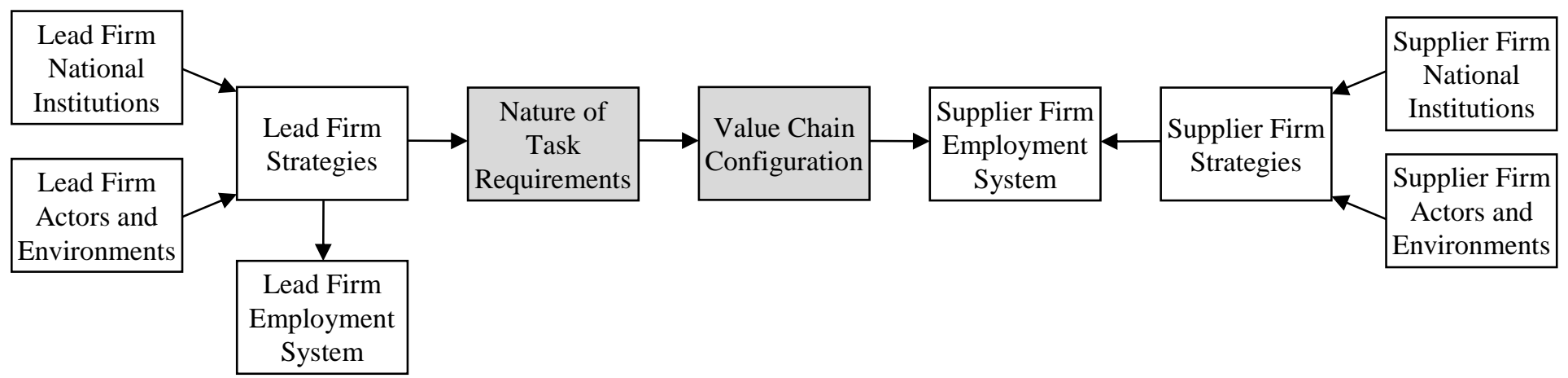

Figure 2: A Configurational Approach to Studying Employment Relations 
Table 1: A Configurational Framework for Employment Relations

\begin{tabular}{|c|c|c|c|c|c|}
\hline \multirow[b]{2}{*}{$\begin{array}{l}\text { Value Chain } \\
\text { Configuration }\end{array}$} & \multirow[b]{2}{*}{$\begin{array}{l}\text { Nature of Task } \\
\text { Requirements }\end{array}$} & \multicolumn{4}{|c|}{ Employment System Criteria } \\
\hline & & $\begin{array}{l}\text { Lead Firm } \\
\text { Influence on } \\
\text { Supplier } \\
\text { Employment } \\
\text { Relations }\end{array}$ & $\begin{array}{c}\text { Skill \& } \\
\text { Knowledge of } \\
\text { Employees in } \\
\text { the Supplier } \\
\text { Firm }\end{array}$ & $\begin{array}{c}\text { Stability of } \\
\text { Employment } \\
\text { in the } \\
\text { Supplier } \\
\text { Firm }\end{array}$ & $\begin{array}{c}\text { National } \\
\text { Institutional } \\
\text { Influences on } \\
\text { Supplier } \\
\text { Employment } \\
\text { Relations }\end{array}$ \\
\hline Market & $\begin{array}{l}\text { - Low task } \\
\text { complexity } \\
\text { - High task } \\
\text { codifiability } \\
\text { - High supplier } \\
\text { capability }\end{array}$ & Low & Low & Low & Local \\
\hline Modular & $\begin{array}{l}\text { - High task } \\
\text { complexity } \\
\text { - High task } \\
\text { codifiability } \\
\text { - High supplier } \\
\text { capability }\end{array}$ & Low & Moderate & Moderate & Local \\
\hline Relational & $\begin{array}{l}\text { - High task } \\
\text { complexity } \\
\text { - Low task } \\
\text { codifiability } \\
\text { - High supplier } \\
\text { capability }\end{array}$ & Moderate & High & High & Local and Lead \\
\hline Captive & $\begin{array}{l}\text { - High task } \\
\text { complexity } \\
\text { - High task } \\
\text { codifiability } \\
\text { - Low supplier } \\
\text { capability }\end{array}$ & High & Low & Low & Local and Lead \\
\hline Hierarchy & $\begin{array}{l}\text { - High task } \\
\text { complexity } \\
\text { - Low task } \\
\text { codifiability } \\
\text { - Low external } \\
\text { supplier } \\
\text { capability }\end{array}$ & High & High & High & Lead \\
\hline
\end{tabular}




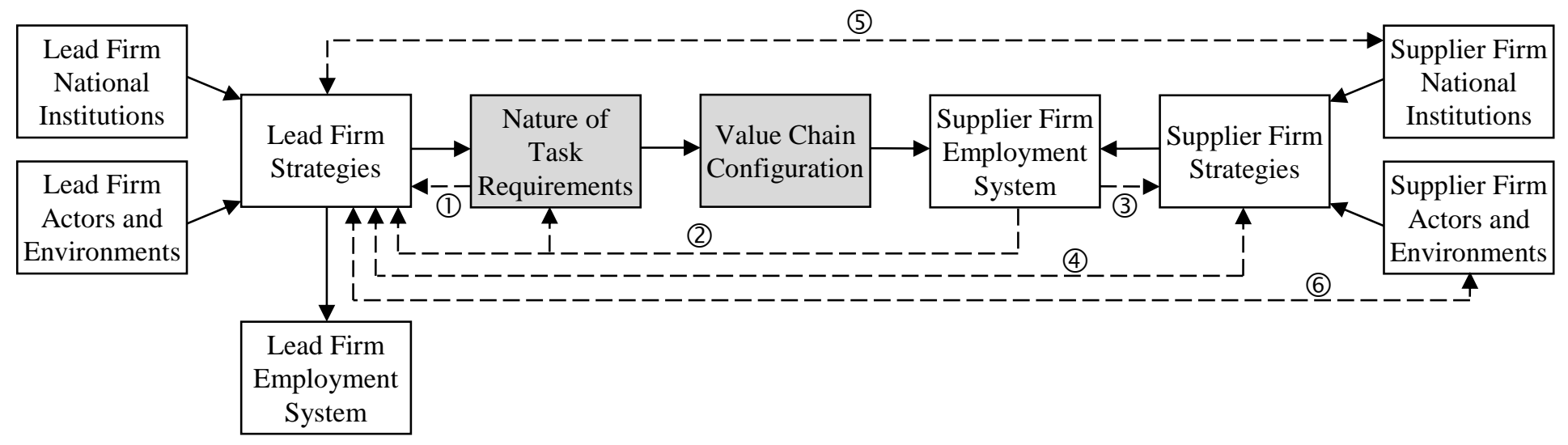

Figure 3: The Dynamics of the Configurational Framework 
${ }^{1}$ We do not debate whether Dunlop's system framework is a theory, although we recognize that it is a debatable issue. Hence, we use theories/frameworks in an interchangeable way in this paper.

${ }^{2}$ In this paper, we use the term "configuration" to refer to the intra- and inter- firm linkages specified by GVC theory because it is a more encompassing term than simply "governance". The term configuration is more analytically useful than governance because the latter implies that we are referring only to the direct relationship or interaction between a lead firm and its supplier while the former reflects the fact that each linkage is composed not only of the interaction between the two parties, with differing levels of explicit coordination and power asymmetry (i.e. mode of governance), but also of different variables, or task requirements, which are the key determinants of each governance form.

${ }^{3}$ While Gereffi does recognize the importance of institutional context or the "rules of the game" on the organization and operation of value chains in some of his previous work (i.e. Gereffi 1995), the theory offered by Gereffi et al (2005) which we are referring to here really doesn't touch on this. Instead, the focus is on the interconnections between firms. However, many scholars (e.g. Lane 2008; Lane and Probert 2009) have called for a greater integration of GVC and institutional approaches (two of which we outlined earlier). Although not our main focus, we do consider some of the implications of connections between firms and different institutional contexts in our proposed framework. This is discussed in more detail in the next section.

${ }^{4}$ Despite criticisms of the chain metaphor, in this paper we adopt a broader view of value chains, consistent with Hopkins and Wallerstein's (1986) definition of commodity chains, and thus use the terms "value chain" and "network" interchangeably.

${ }^{5}$ While some have distinguished between the notion of "governance as drivenness" and "governance as coordination" (e.g. Bair 2009; Riisgaard and Hammer 2011), no such distinction is made here. Instead, we not only view each value chain configuration as the relationship between two links in the chain (consistent with the notion of "governance as coordination") but also see each configuration as driven, in large part, by a lead firm with the power to shape rules and outcomes in the chain (consistent with the notion of "governance as drivenness").

${ }^{6}$ While we might expect the number and the skill/knowledge mix of employees in lead firms to change as lead firms establish connections to outside firms and more work moves outside the firm's boundaries, we would not expect there to be differences in the employment relations strategies and practices for remaining, typically high skilled, employees in the lead firm as a result of the lead firm's involvement in one type of value chain configuration or another with external suppliers. This is not to say that outsourcing itself won't have an impact on lead firm employment relations strategies and practices but rather that the specific type of value chain configurations that lead firms engage in with outside supplier firms (i.e. market vs. modular vs. captive etc) will not have differential effects on the structure and outcomes of employment systems inside the lead firm. In contrast, we argue that there will be differences in the employment relations strategies and practices of supplier firms as a result of their involvement in different value chain configurations due to differences in the nature of task requirements and supplier relationships with lead firms. Accordingly, since we are interested in examining how value chain configurations shape employment relations systems, the focus here will be on suppliers rather than lead firms. Moreover, insights about lead firm employment systems can be gleaned from what are, in effect, separate value chain configurations between the lead firm and its in-house suppliers (or subsidiaries). As we discuss later on, this will often, though not always, be reflected by the hierarchical value chain configuration.

${ }^{7}$ As Lane and Probert (2009) demonstrate in their analysis of global value chains in the clothing industry, different home country institutional environments may be associated with different lead firm competitive strategies, value chain configurations and, in turn, employment relations outcomes. German clothing firms, for example, were found to organize their value chains through more relational approaches while U.S. firms were more likely to use marketbased configurations.

${ }^{8}$ As noted above, value chain configurations are likely to both shape and be shaped by employment systems. Specific aspects of employment systems, such as the availability of certain types of skills, may be deciding factors in lead firms choosing one value chain configuration over another and changes in skills may be associated with changes in value chain configurations over time. Nevertheless, while configurational choices may initially be influenced by particular characteristics of employment systems, value chain configurations, once established, play a significant role in preserving those characteristics (e.g. through tasks that are matched to existing skill levels) and shaping other elements of employment systems. This is not to say that learning and upgrading in value chains is not possible but rather that each value chain configuration has dramatically different implications for the structure and outcomes of employment relations systems. Accordingly, we are concerned here with understanding what these 
implications are. The dynamics of global value chains, including the ways in which employment systems can shape value chain configurations, will be discussed later in the paper.

${ }^{9}$ While many firms have begun to externalize non-core functions, keeping in-house only those activities which are the highest value-added, this is certainly not the case for all firms. For example, some firms continue to control and own non-core manufacturing and assembly functions. For the purposes of our framework however, we will categorize intra-firm relationships over core functions as hierarchical and will expect relationships between lead firms and subsidiaries to reflect the characteristics and employment system criteria described here. On the other hand, the characteristics and employment system criteria for intra-firm relationships between lead firms and subsidiaries over non-core functions may be reflected in any of the five value chain configurations based on the nature of task requirements in those functions. 